\title{
Wavelet Analysis of X-ray Densify Function of Tree Ring Structure
}

\section{Wavelet analiza funkcije gustoće godova stabla određene X-zrakama}

\author{
Original scientific paper • Izvorni znanstveni rad \\ Received-prispjelo: 30. 6. 2015. \\ Accepted-prihvaćeno: 5. 5. 2016. \\ UDK: $630 * 811.4 ; 630 * 812.31$ \\ doi:10.5552/drind.2016.1528
}

\begin{abstract}
The annual ring density of cross-sections of Japanese cedar stems of different ages has been recorded by X-ray density analyser in order to determine the boundary line between juvenile and mature wood. A particular emphasis was put on the tracheid length in the annual rings. The obtained data was analysed by using Wavelet transformation. It can be assumed that the process of formation of woody tissue is a periodic one and that the characteristic periods include several annual rings. This also indicates that the growth of a tree can be separated into distinct processes that can be identified within the juvenile and mature wood zones. It has been shown that the suggested numerical approach enables a rapid and reliable evaluation of the data.
\end{abstract}

Key words: Juvenile/mature wood, Hurst exponent, tracheid length, X-ray densitometry, wavelet transform

SAŽETAK • Gustoća godova na poprečnim presjecima debla japanskog cedra različite starosti određena je uz pomoć rendgenskog analizatora gustoće kako bi se utvrdila granična linija između juvenilnoga i zrelog drva. Poseban naglasak stavljen je na duljinu traheida u godovima. Dobiveni su podatci analizirani uz pomoć wavelet transformacije. Može se pretpostaviti da je proces formiranja drvnog tkiva periodičan i da karakteristična razdoblja obuhvaćaju nekoliko godova. To također pokazuje da se rast stabla može podijeliti u različite procese koji se mogu identificirati unutar zone juvenilnoga i zrelog drva. U radu je utvrđeno da predloženi numerički pristup omogućuje brzu i pouzdanu procjenu podataka.

Ključne rïječi: juvenilno/zrelo drvo, Hurstov eksponent, duljina traheida, rendgenska denzitometrija, wavelet transformacija

\section{INTRODUCTION \\ 1. UVOD}

Juvenile wood formation is an important natural process in stem growth and it has been widely studied in the last 50 years (Gartner, 1996; Larson, 1968; Yang et al., 1994). Juvenile and mature wood refers to two main zones of the xylem. Juvenile wood becomes especially interesting for forestry because of the short rotation cycle that is typical in plantation forestry. Re- cently, as a result of change in forestry management, the proportion of juvenile wood in tree stems has increased. This may have a major effect on wood properties and product quality, especially in conifers (Maeglin, 1987). The juvenile wood boundary can be determined by examining a number of different physical or chemical properties (Wang and Stewart, 2013).

Many studies in the area of wood anatomy use only one or two wood attributes to define the demarcation line between juvenile and mature wood. Such meth-

\footnotetext{
Author is an assistant at University of West Hungary, Institute of Wood Based Products and Technologies, Sopron, Hungary.

${ }^{1}$ Autor je asistent Sveučilišta zapadne Mađarske, Odjel za proizvode od drva i drvnu tehnologiju, Sopron, Mađarska.
} 
ods have been widely accepted as the norm for assessing wood juvenility. Unfortunately, these studies did not take into account the complexity of the stem. For example, for a long time, the measurement of annual ring width, specific gravity, tracheid length and microfibril angle have been the most prevalent methods (Fujisaki, 1985; Fukazawa, 1967; Matyas and Peszlen, 1997; Ota, 1971; Yang et al., 1986; Zhu et al., 2000). Studies in this area also focused on the non-linear, segmented regression method of tracheid length and microfibril angle (Cook and Barbour, 1989; Zhu et al., 2005). Based on these methods, the transition is referred to as a zone of gradual changes, rather than an exact demarcation line. These studies have obviously provided a common and simple tool for analysing the growth variation. However, the global nature of the above mentioned processes hides local density-distribution information, and makes the exact determination of distance-related changes impossible. For this reason, the researchers turned to the $\mathrm{X}$-ray density function of the wood and used different mathematical methods to draw information about the wood properties.

The X-ray density profile is the result of the superposition of many different environmental factors, such as rainfall, soil and site conditions, temperature, etc., which cause periodic changes in density along the radius. Franceschini et al. (2010, 2013) used the mean ring density profile to study the radial pattern variations and their consistency with changes in temperature and climate. Mutz et al. (2004), applied the nonlinear mixed-effects model to the average density profile of Scots pine trees in order to statistically model the stem growth. X-ray density profile was also used for determination of the transition from juvenile to mature wood (Koubaa et al., 2002; Fujimoto et al., 2006).

Our work focuses on the development of different mathematical procedures for the analysis of X-ray density function (XDF) that may enable better understanding of the growth of individual trees along the radius of their bole. In our previous studies (Csoka et al. 2005, 2007), we applied Fourier transform to the X-ray density function in order to determine the line that separates the juvenile and mature zones in the tree stem. In the present paper, we will show that the spectral wavelet analysis (Torrence and Compo, 1998; Hurst, 1951) of the X-ray density function can provide information about anatomical variations in the representative sugi trees (Cryptomeria japonica D. Don). The wavelet transformation, basically, enables one to draw additional data from the XDF signal. Rozenberg et al. (2001) analysed cloning and genetic effects of the Norway spruce by multi-resolution methods of the density profile, and published preliminary results on wood homogeneity using wavelets decomposition. Solomina et al. (2010) used wavelet transformation of the early wood ring width and maximum density profiles to study changes induced by climatic fluctuations and solar activity. Here, wavelet analysis was applied to investigate the transition from juvenile to mature wood. The advantage of the wavelet analysis, with respect to previously used Fourier analysis, is that the one-dimensional density set is transformed into a diffuse, two-dimensional distance-frequency image. In the obtained transform, the density frequency of annual rings and their distances from the pith may be studied simultaneously. It should also be noted that the previous studies used only the average or maximum density of annual rings in their calculations. Here, the wavelet transform was applied to the whole set of X-ray density data.

\section{METHODS AND MATERIALS} 2. MATERIJALI I METODE

In order to sample the independent applicability of the wavelet method with respect to tree life span, the X-ray density profiles of 18 selected Japanese cedar tree stems (from 28-221 year old) were included in our analysis. Here, three stems were selected for detailed analysis (221, 95 and 28 year-old) and the results of the other samples can be found in the supplementary file. The first two stems were taken from natural forest (marked as nf221, nf95) and the third one (the youngest one) was taken from a plantation forest (marked as pf28). The samples were cut at breast height $(120 \mathrm{~cm})$ of the stems. The growth ring density curve was obtained by X-ray densitometry (JL Automation 3CSPC). The density curve from the pith to the bark was recorded to determine the amplitude of the density oscillation.

\subsection{Measurement of the tracheid length}

\subsection{Mjerenje duljine traheida}

Small blocks taken from every third annual ring (late wood) were placed in a bottle with a macerating solution (1:1 v:v, $30 \%$ hydrogen peroxide : glacial acetic acid) and left for 48 hours. During this time the blocks began to break down into fragments and the tracheids were liberated. After washing several times, the tracheids were placed on a glass slide and the length (30 different at every third annual ring) was measured manually by using light microscopy (Carl Zeiss, Jena, Germany).

\subsection{Wavelet analysis \\ 2.2. Wavelet analiza}

The present study is an extension of our previous work on Fourier transform analysis of X-ray density profiles of Japanese cedar (Csoka et al., 2005; Csoka et al., 2007). The wavelet transform is similar to the commonly used Fourier transform but it proved to be a better method in the case of more complex systems. Wavelet transformation uses windows of different sizes and positions to analyse a signal, which enables a fine resolution and control without restriction of the scale of detectable phenomena. The wavelet transform can be used to analyse time series that contain nonstationary amplitude points at many different frequencies (Daubechies, 1990).

The continuous wavelet transform of a discrete sequence $x_{n}$ (density function of a tree) is defined as the convolution of $x_{n}$ with a scaled and translated version of the mother wavelet $\psi_{0}(\eta)$ : 


$$
W_{n}(s)=F F T^{-1}\left[\sum_{k=0}^{N-1} \hat{X}_{k}\left(\sqrt{\frac{2 \pi s}{\delta t}} \hat{\psi}_{0}\left(s \omega_{k}\right) e^{i \omega_{k} n \delta t}\right)\right]
$$

where: $N$ is the length of the data series, $s$ is the wavelet scale, $d t$ is the sampling interval $(0.015 \mathrm{~mm}), n$ is the localized distance index, $\omega_{k}$ is the angular frequency and $x_{k}$ is the discrete Fourier transform. The normalisation is included in the equation above in such a way that the wavelet function contains unit energy at every scale. In this way defined wavelet transformation enables simultaneous extraction of the distance and frequency information from the signal. The density function of the tree is non-stationary and wavelet analysis was selected to extract the relevant distance-density information from the signal. In this study, the Morlet $\left(\pi^{1 / 4} H(\omega) e^{-(s \omega-m)^{2} / 2}\right)$ and Paul $\left(\frac{2^{m}}{\sqrt{m(2 m-1)}} H(\omega)(s \omega)^{m} e^{-s \omega}\right)$ mother-wavelet bases were selected for spectral analysis and for the resolution of strong frequency components. The wave number and the Heaviside step function are in the chosen bases. In the wavelet analysis, the factors of Morlet and Paul mother wavelets are very important, because they affect both the peak intensity and the data range. Both bases were used for the wavelet transformation of the XDF signals of our samples. It turned out that the Morlet's basis gave a more distinct picture in the case of the younger samples (pf28 and nf95), while the Paul's basis gave better results in the case of the oldest sample (nf221). When the wavelet analysis was applied to geophysical phenomena, $\omega_{k}$ between 5 and 6 was used in order to attain the sufficient precision in the distance or time domains. For this reason, this condition was also selected. The signal analysis was performed by using AutoSignal software.

\subsection{Calculation of the Hurst exponent}

\subsection{Izračun Hurstova koeficijenta}

The statistical operator, the Hurst exponent $(H)$, measures the fractal dimension of a time set and it can be obtained from the following linear regression:

$$
\log (R / S)_{n}=\log c+\log n
$$

where the range $R$ is divided by the standard deviation $S$ of the $n$ data elements to produce the normalized range value $(R / S)$ and $c$ is a constant. The parameter $H$ calculated from the slope of the linear function given by Eq. 2 is in the range from 0 to 1 . The $R / S$ analysis is non-parametric; there is no assumption about the shape of the underlying distribution. The set of XDFs is similar to log-normal distribution. Series with $H$ values larger than 0.5 are persistent series that contain a memory effect. Each data value is related to a certain number of preceding values. The $k(n o b s)$ provides information about the number of cycles, which shows dependence upon the past. These data series reverse signs less frequently than in the case of the white noise.

\section{RESULTS AND DISCUSSION}

\section{REZULTATI I RASPRAVA}

Different environmental effects can cause severe disruption of growth function (Dobbertin, 2005). Many physical changes can be identified visually, but the most subtle variations can only be noticed by the numerical analysis of the density of annual rings. In the wavelet analysis of the X-ray density profiles of the three sugi trees, the probability amplitudes vary as a function of frequency and distance. The wavelet spectrum of XDF was found fluctuating on inter-distance scales.

The calculated wavelet plots presented in Figure $1 \mathrm{a}, \mathrm{b}$ and $\mathrm{c}$ show different growth cycle periods of the tree. The thick, black contour indicates the regions where the amplitude of the waves can be found with confidence level of more than $95 \%$ and the growth of annual rings is very uniform.

Morlet mother-wavelet basis set was used in the case pf 28 and nf95 samples, while the Paul (c) basis set was used for the nf221 sample. Fourier frequencies are given on the vertical axis in $\mathrm{mm}^{-1}$ (that correspond to annual ring widths in $\mathrm{mm}$, given on the right). The distance from the pith to the bark is given on the horizontal axis. The grayscale gradient plot indicates the major contours where the transitions occur. Most peaks are well above the background spectrum (light grey colour). The black contours enclose regions where the amplitudes can be found with a confidence level higher than $95 \%$. The variation in growth projected on the wavelet scalogram can be related to the annual ring increments. However, wavelet analysis shows that growth cycle periods are distinctly grouped. The whole growth cycle can be separated into well correlated segments within the frequency and distance domains. Note that the correlated segments reflect the growth behaviour of the trees along the distance from the pith to the bark, the process which cannot be clearly observed if only the frequency domain is taken into account. Also, as distance from the pith to the bark increases, the differences between the gradients become uneven. Figures 1 (a),(b), (c) show that in the area of low distances and low frequencies the gradient is low (mostly light gray) and there is no significant correlation between the waves.

Figure 1a shows the wavelet spectrum of the 28 year old sugi tree (pf28). This data set encloses the frequency range from 0.2 to $0.35 \mathrm{~mm}^{-1}$, which corresponds to the annual ring width from 5 to $2.8 \mathrm{~mm}$. The main amplitude contours are located in the mentioned frequency range and they are divided in two groups. The first one includes 14 and the second one 7 annual rings. At the distances between 40 and $60 \mathrm{~mm}$, there is a breaking point, where the most correlated grouping appeared in the lower frequency range due to some environmental anomaly (changes in local climatic conditions). This means that in the range prior to the breaking point, the width of the annual rings is narrower than after (Fig 1a). At distances higher than $80 \mathrm{~mm}$, there is an increase in frequencies (a decrease in the ring widths) suggesting the presence of areas of different anatomy. The distance range, in which the change in the wavelet spectra took place, can be considered as a demarcation line of the transition from juvenile to mature wood in this sample. The wavelet spectrum of the 

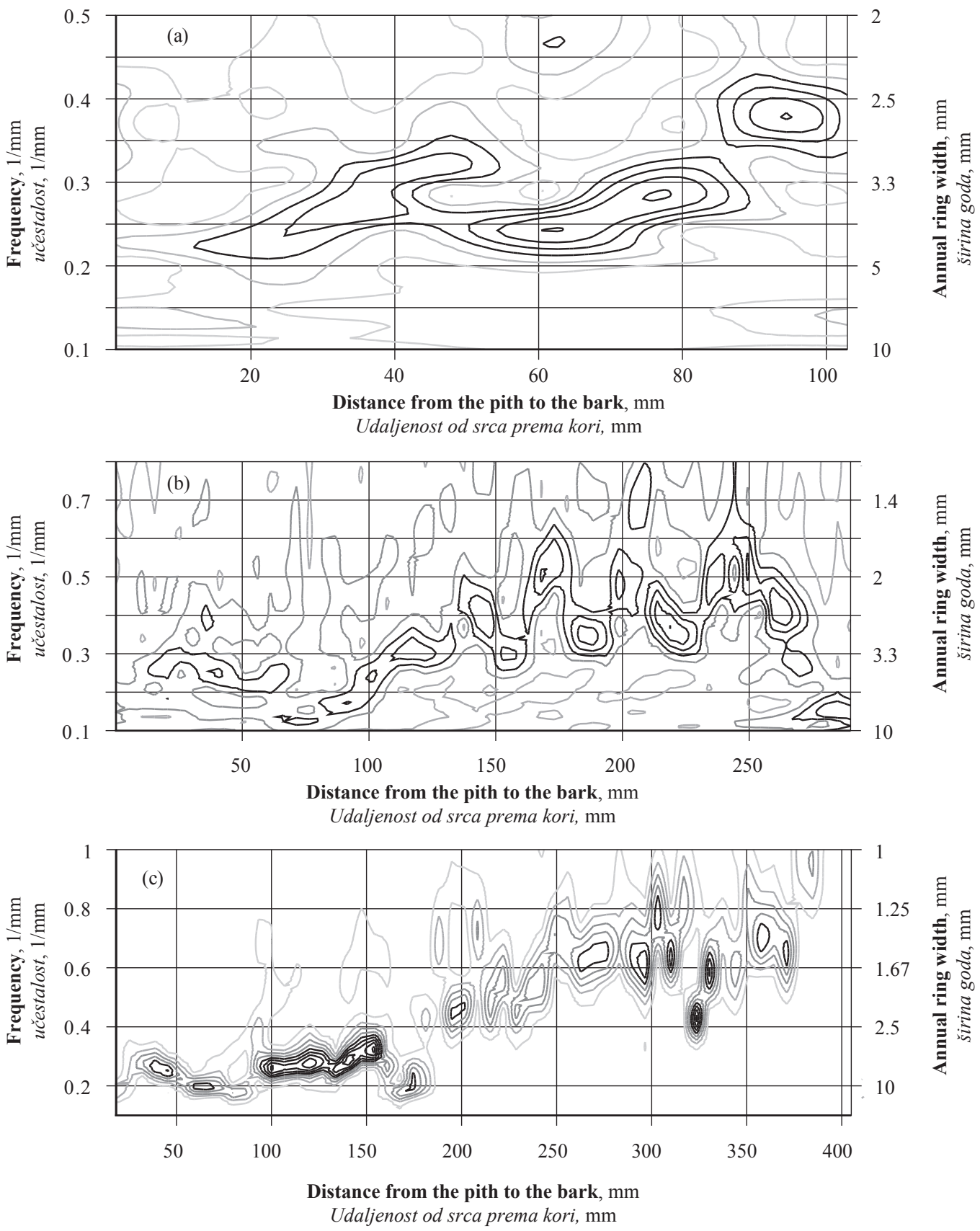

Figure 1 The local wavelet power spectra of X-ray density functions of a) pf28, b) nf95 and c) nf221 samples Slika 1. Lokalni wavelet spektar funkcije gustoće određene X-zrakama za uzorke: a) pf28, b) nf95 i c) nf22

95 year old sugi tree (sample nf95) is shown in Figure 1b. This spectrum includes a wider frequency range $\left(0.15-0.6 \mathrm{~mm}^{-1}\right)$ and it is more distinctive than in the case of the pf 28 sample. The wavelet spectrum in the distance range below $75 \mathrm{~mm}$ is quite complex, suggesting that various environmental factors (probably climatic factors) contributed to the tree ring formation. The transition point from juvenile to adult wood is most likely positioned in the distance region from 30 to $75 \mathrm{~mm}$, where there is a clear drop in the position of black contours that represent high probability amplitude regions. As the distance further increases, the wavelet contours become very disordered. At distances around $130 \mathrm{~mm}$, there are several black contours that mainly contain 7 annual rings.

Figure 1 (c) shows the wavelet spectral feature of the 221 (nf221) year old sugi tree. The first distinct fre- quency group, up to $90 \mathrm{~mm}$ from the pith, contains 23 annual rings. In that group, the width of the annual rings is continuously increasing as a result of the initial growth of the tree. At the distance of $90 \mathrm{~mm}$, the frequency falls to approximately $0.1 \mathrm{~mm}^{-1}$ and this value corresponds to the transition point between juvenile and mature wood. The next frequency group (in the distance region from 90 to $170 \mathrm{~mm}$ ) contains 25 annual rings and the results suggest that in that region the growth became more regular. For this sample, the contours with highest amplitude probability are mostly located in the frequency regions from 0.43 to $1.1 \mathrm{~mm}^{-1}$ (from 2.3 to $0.9 \mathrm{~mm}$ ring width) and from 0.17 to $0.4 \mathrm{~mm}^{-1}$ (from 5.8 to 2.5 $\mathrm{mm}$ ). The rhythmic structure of short and long-term cycles in the tree-ring chronologies is most likely related to the climatic fluctuations and solar activity (Nowacki and Abrams, 1997). In the study on early wood ring widths, 

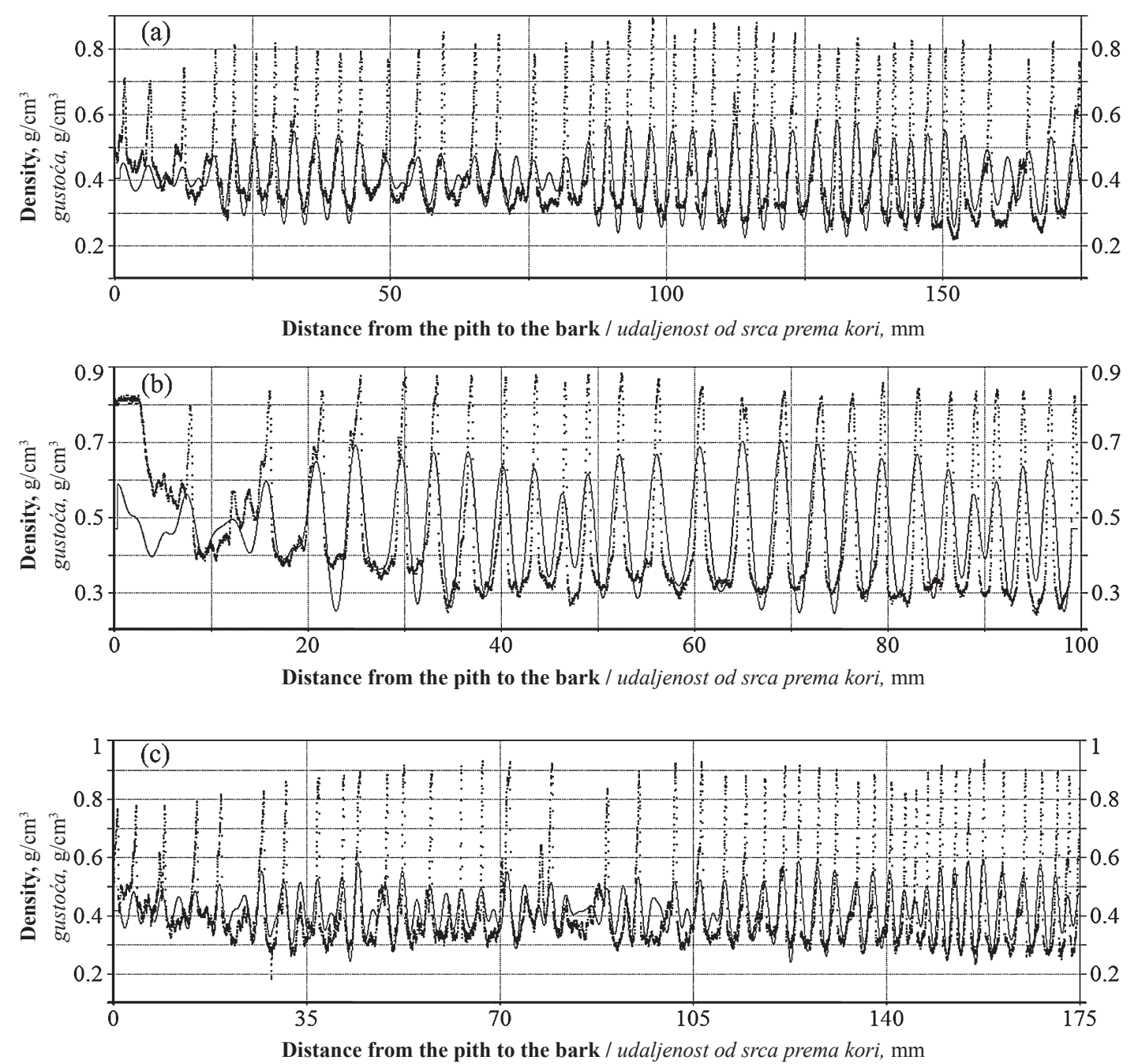

Figure 2 Experimentally obtained (solid line) and reconstructed (dashed line) density spectra of a) pf28, b) nf95 and c) nf221 samples. For clarity, the reconstructed density spectra of nf95 and nf221 samples were shown in the distance range from 0 to $175 \mathrm{~mm}$

Slika 2. Eksperimentalno dobiveni (puna linija) i rekonstruirani (isprekidana linija) spektri gustoće za uzorke: a) pf28, b) nf95 i c) nf221 (radi jasnoće, rekonstruirani spektri gustoće za uzorke nf95 i nf221 prikazani su u rasponu od 0 do $175 \mathrm{~mm}$ )

Solomina et al. (2010) obtained similar results by using wavelet transformation and the maximum densities of the rings. It is worth emphasizing that in our calculations, we used the whole set of density data and not only the maximum densities of the rings. The transition points determined by using wavelet method correspond well to the results obtained by Fourier transform method (Csoka et al., 2005, 2007; Csoka and Djokovic, 2011) and logarithmic regression method of tracheid lengths (TL), which will be presented below. The fact that we were able to determine the distinct transition points contradicts the common opinion that a juvenile gradually turns into a mature wood. The annual ring growth of the trees is a periodic one and influenced by its response to the environmental impacts. These environmental effects induced changes in the boundary between the two main zones from the pith, but the clear separation point still exists. It is important to note that the growth cycles are not significantly affected by tree ageing but there are apparent structural changes during the juvenile formation (Castagneri et al., 2013).
During the wavelet transform calculations, we have omitted certain peaks of low probability. In Figure 2 (a), (b), (c), the density function was reconstructed by using inverse wavelet transformation of the data that are included in the initial calculations. As can be seen, there is a good agreement between the experimentally obtained and reconstructed density function. The low probability peaks in the reconstructed spectra of pf $28, \mathrm{nf} 95$ and nf221 samples observed in the 80-92 $\mathrm{mm}, 65-100 \mathrm{~mm}$ and 50-90 $\mathrm{mm}$ regions, respectively, correlate with the initial growth pattern of the trees. These ranges are the finger print of the events in the juvenile age of the woods. The density fluctuations, before and after these bands, are more uniform. The spectral analysis performed in this work shows that the density function of the investigated species carry the information about juvenile-mature transitions that seemed to be affected by the local environment.

The Hurst plots of three samples presented in Figure 3 suggest that the density functions are substantially homogeneous. 

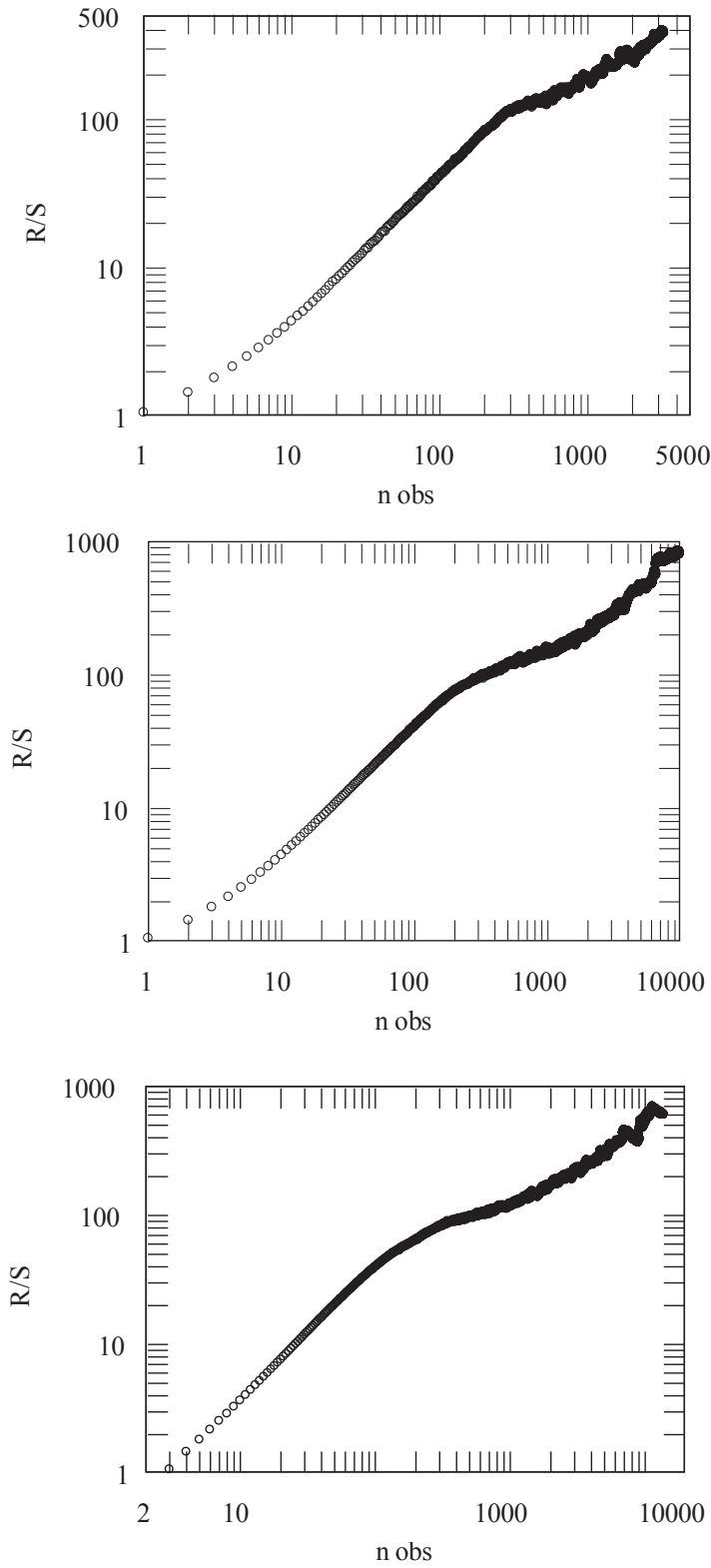

Figure 3 Hurst plots (normalized range value $(R / S)$ versus number of observations) of a) pf28, b) nf95 and c) nf221 samples. (Hurst coefficients were estimated by linear regression $r^{2}=0.94,0.93$ and 0.99 for the pf28, nf95, nf221 samples, respectively)

Slika 3. Hurstovi grafovi (normalizirani raspon vrijednosti $(R / S)$ u odnosu prema broju opažanja) za uzorke: a) pf 28, b) nf95 i c) nf221. (Hurstovi koeficijenti procijenjeni su uz pomoć linearne regresije $r^{2}=0,94$ za uzorak pf $28, r^{2}=0,93$ za uzorak nf95 i $r^{2}=0,99$ za uzorak nf221.)

The values of the Hurst exponents are well above 0.5 in the whole life span of the tree. The calculated values are $0.88,0.93$ and 0.76 for the $\mathrm{pf} 28, \mathrm{nf} 95$ and nf221 samples, respectively. The shape of the plots indicates that the periodic growth pattern of the trees is essentially similar during the whole life span. The growth can be predicted to a certain extent knowing the initial growth stages and the data set is obviously distinguishable from Gaussian or white noise. The values of the Hurst exponent that lie between 0.5 and 1 characterise the so-called black noise processes, long-run cyclical patterns that are readily observable in nature
(Peters 1994). This implies that the formation of individual annual rings is affected by the environment. However, these effects cannot significantly change the shape of the annual rings. Since the Hurst exponent values are much higher than 0.5 , and they were estimated from a long series of data points $(>5000)$, the $\mathrm{X}$-ray density function is substantially different from the noise and can reliably represent the annual growth of trees. Knowing the density function and the Hurst exponent, it is possible to predict the growth of annual rings, which can be further integrated into the local environment model.

Figure 4 shows the results obtained with tracheid length (TL) method. The TL values show typical functional dependence on annual ring number.

The TL values increase exponentially at early stages of the tree growth up to 25 years. After that, the TL exhibits stability or increases gradually over the time. Similar results on TL variability were reported earlier by Franceschini et al. (2012). The radial variations in TL were tentatively fitted with the logarithmic curve with a high correlation coefficient. The annual rate increment of TL was calculated from the logarithmic curve by using the point at which the annual increase rate drops below $1 \%$ (Zhu et al., 2000). According to Shiokura (Shiokura 1982), the annual ring number at which TL increment rate drops below $1 \%$ is related to the transition point between juvenile and mature wood. The transition point values obtained from the segmented model of tracheid lengths are in good agreement with the values calculated by using wavelet transform, but the two methods are independent (Table 1).

The localised waves in the wavelet spectrum obviously carry information about anatomical changes during the tree growth. For this reason, the wavelet analysis can be considered as an excellent tool for studying wood properties.

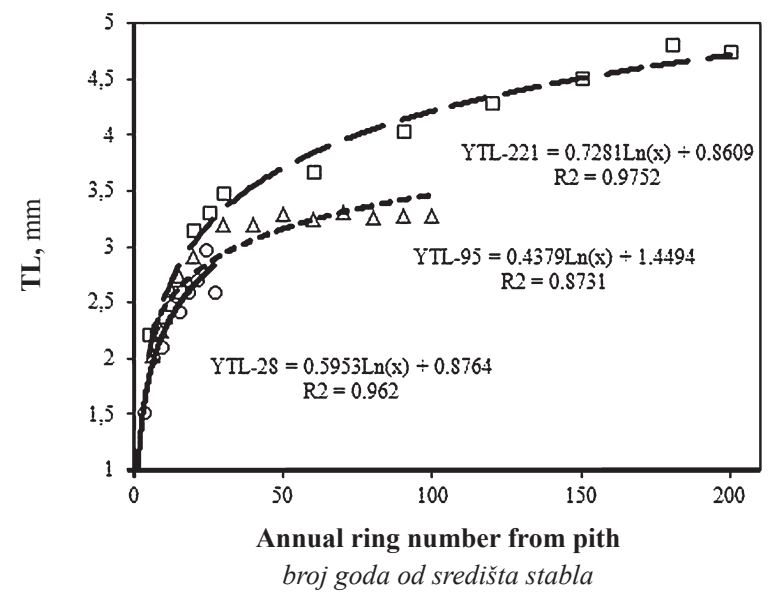

Figure 4 Radial variation of tracheid length (TL) for pf 28 (circles), nf95 (triangles nf221 (squares) samples. The lines represent logarithmic curves of TL-s estimated from the experimental data

Slika 4. Radijalna varijacija duljine traheida (TL) za uzorak pf28 (krugovi), uzorak nf95 (trokuti) i uzorak nf221 (kvadrati). Linije predočuju logaritamske krivulje duljine traheida procijenjene iz eksperimentalnih podataka. 
Table 1 Transition points between juvenile and mature wood determined by measuring tracheid lengths and by using Wavelet analysis

Tablica 1. Prijelazne točke između juvenilnoga i zrelog drva određene mjerenjem duljine traheida i uz pomoć wavelet analize

\begin{tabular}{|c|c|c|c|c|c|}
\hline \multirow[b]{2}{*}{$\begin{array}{l}\text { Sample tree } \\
\text { Uzorak } \\
\text { stabla }\end{array}$} & \multirow[b]{2}{*}{$\begin{array}{c}\text { Tree age, } \\
\text { years } \\
\text { Starost stabla }\end{array}$} & \multicolumn{2}{|c|}{$\begin{array}{l}\text { TL regression results } \\
\text { Rezultati regresijske analize duljine traheida }\end{array}$} & \multicolumn{2}{|c|}{$\begin{array}{l}\text { Wavelet spectrum } \\
\text { Wavelet spektar }\end{array}$} \\
\hline & & $\begin{array}{l}\text { Annual ring number } \\
\text { from pith } \\
\text { Broj godova od srca }\end{array}$ & $\begin{array}{c}\text { Distance from } \\
\text { the pith, mm } \\
\text { Udaljenost od srca, } \\
\mathrm{mm}\end{array}$ & $\begin{array}{l}\text { Annual ring number } \\
\text { from pith } \\
\text { Broj godova od srca }\end{array}$ & $\begin{array}{c}\text { Distance from } \\
\text { the pith, mm } \\
\text { Udaljenost od srca, } \\
\text { mm }\end{array}$ \\
\hline pf28 & 28 & $21-22$ & $82-85$ & $21-22$ & 84.9 \\
\hline nf95 & 95 & $14-15$ & $59-65$ & $14-15$ & 64.7 \\
\hline $\mathrm{nf} 221$ & 221 & $22-23$ & $95-98$ & $21-22$ & 94.2 \\
\hline
\end{tabular}

\section{CONCLUSION}

\section{ZAKLJUČAK}

Wavelet analysis can significantly increase the body of information that can be obtained from the investigated signal. It allows simultaneous study of the distance-density domains of the X-ray density function. Even when the signal is quasi non-stationary, as in the case of $\mathrm{XDF}$, the distance domain information can make analysis more precise. In the case of the transition between juvenile and mature wood, wavelet analysis provides the same results as traditional methods in wood science. However, it also enables one to draw additional information about the environmental factors that affect the wood anatomy, which cannot be observed by using former methods. It can be assumed that the process of formation of the wood tissue is a periodic one and that the characteristic periods include several annual rings. This also indicates that the growth of wood can be separated into distinct processes that can be identified within the juvenile and mature wood zones. The presented results strongly support the use of wavelet transformation of XDF in studying the properties of the wood. Nevertheless, further investigations are necessary in order to reveal the potentials and limitations of the wavelet analysis in this particular field.

\section{REFERENCES}

\section{LITERATURA}

1. Castagneri, D.; Storaunet, K. O.; Rolstad, J., 2013: Age and growth patterns of old Norway spruce trees in Trillemarka forest, Norway. Scandinavian Journal of Forest Research, 28: 232-240. http://dx.doi.org/10.1080/02827581.2012.724082.

2. Cook, J. A.; Barbour, R. J., 1989: The use of segmented regression analysis in the determination of juvenile and mature wood properties. Report CFS No. 31. Forintek Canada, Corp., Vancouver, BC.

3. Csoka, L.; Zhu, J.; Takata, K., 2005: Application of the Fourier analysis to determine the demarcation between ju-

\section{Supplementary material - Dodatni podatci}

The following supplementary data (S1) is available at Drvna Industrija online: additional results on more wood samples can be found in the supplementary file.

\begin{tabular}{|l|c|c|c|c|c|}
\hline \multirow{2}{*}{$\begin{array}{c}\text { Sample tree } \\
\text { Uzorak stabla }\end{array}$} & $\begin{array}{c}\text { Tree age, years } \\
\text { Starost stabla }\end{array}$ & $\begin{array}{c}\text { TL regression results } \\
\text { Rezultati regresijske analize duljine traheida }\end{array}$ & $\begin{array}{r}\text { Wavelet spectrum } \\
\text { Wavelet spektar }\end{array}$ \\
\cline { 3 - 6 } & & $\begin{array}{c}\text { Annual ring } \\
\text { number from pith } \\
\text { Broj godova od srca }\end{array}$ & $\begin{array}{c}\text { Distance from } \\
\text { the pith, mm } \\
\text { Udaljenost od srca, } \\
\text { mm }\end{array}$ & $\begin{array}{c}\text { Annual ring } \\
\text { number from pith } \\
\text { Broj godova od } \\
\text { srca }\end{array}$ & $\begin{array}{c}\text { Distance from } \\
\text { the pith, mm } \\
\text { Udaljenost od } \\
\text { srca, } \text { mm }\end{array}$ \\
\hline C1 & 28 & $21-22$ & $96-98$ & $22-23$ & 97.37 \\
\hline pf28 & 28 & $21-22$ & $83-86$ & $21-22$ & 84.9 \\
\hline C33 & 30 & $21-22$ & $110-113$ & $21-22$ & 111.15 \\
\hline C36 & 29 & $20-21$ & $100-105$ & $20-21$ & 104.17 \\
\hline C39 & 29 & $18-19$ & $94-99$ & $18-19$ & 98.12 \\
\hline T6 & 75 & $21-22$ & $71-74$ & $21-22$ & 71.45 \\
\hline T8 & 73 & $24-25$ & $61-64$ & $25-26$ & 65.35 \\
\hline T9 & 73 & $22-23$ & $54-56$ & $23-24$ & 59.52 \\
\hline T10 & 93 & $16-17$ & $40-43$ & $17-18$ & 46.32 \\
\hline IV1 & 94 & $10-11$ & $36-41$ & $10-11$ & 40.17 \\
\hline IV2 & 95 & $14-15$ & $40-43$ & $15-16$ & 47.1 \\
\hline nf95 & 100 & $14-15$ & $59-64$ & $14-15$ & 63.7 \\
\hline VI1 & 94 & $14-15$ & $58-62$ & $14-15$ & 59.72 \\
\hline VI2 & 102 & $15-16$ & $44-51$ & $16-17$ & 53.64 \\
\hline VI3 & 96 & $17-18$ & $89-96$ & $16-17$ & 88.83 \\
\hline VI4 & 216 & $16-17$ & $44-57$ & $17-18$ & 58.94 \\
\hline NRNT T1 & 221 & $22-23$ & $54-57$ & $14-15$ & 52.24 \\
\hline nf221 & & & $97-101$ & $21-22$ & 94.2 \\
\hline
\end{tabular}


venile and mature wood. Journal of Wood Science, 51 (3): 309-311. http://dx.doi.org/10.1007/s10086-005-0722-y.

4. Csoka, L.; Divos, F.; Takata, K., 2007: Utilization of Fourier transform of the absolute amplitude spectrum in wood anatomy. Applied Mathematics and Computation, 193 (2): 385-388.

http://dx.doi.org/10.1016/j.amc.2007.03.073.

5. Csoka, L.; Djokovic, V., 2011: Theoretical Description of the Fourier transform of the Absolute Amplitude Spectra and Its Applications. In: Nikolic GS (ed), Fourier Transforms - Approach to Scientific Principles. InTech, Rijeka, pp. 1-14. http://dx.doi.org/10.5772/15368.

6. Daubechies, I., 1990: The wavelet transform time-frequency localization and signal analysis. IEEE Transactions on Information Theory, 36 (5): 961-1005. http://dx.doi.org/10.1109/18.57199.

7. Dobbertin, M., 2005: Tree growth as indicator of tree vitality and of tree reaction to environmental stress: a review. European Journal of Forest Research, 124 (4): 319 333. http://dx.doi.org/10.1007/s10342-005-0085-3

8. Franceschini, T.; Bontemps, J. D.; Gelhaye, P.; Rittié, D.; Gégout, J. C.; Leban, J. M., 2010: Decreasing trend and fluctuations in the mean ring density of Norway spruce through the twentieth century. Annals of Forest Science, 67 (8): 816-826. http://dx.doi.org/10.1051/forest/2010055.

9. Franceschini, T.; Lundquist, S. O.; Bontemps, J. D.; Grahn, T., Olson, L.; Evans, R.; Leban, J. M., 2012: Empirical models for radial and tangential fibre width in tree ring of Norway spruce in northwestern Europe. Holzforschung, 66 (2): 219-230. http://dx.doi.org/0.1515/HF.2011.150.

10. Franceschini, T.; Longuetaud, F.; Bontemps, J. D.; Bouriaud, O.; Caritey, B. D.; Leban, J. M., 2013: Effect of ring width, cambial age, and climatic variables on the within-ring wood density profile of Norway spruce Picea abies (L.) Karst. Trees-Structure and Function, 27 (4): 913-925. http://dx.doi.org/10.1007/s00468-013-0844-6.

11. Fujimoto, T.; Kita, K.; Uchiyama, K.; Kuromaru, M.; Akutsu, H.; Oda, K., 2006: Age trends in the genetic parameters of wood density and the relationship with growth rates in hybrid larch (Larix g melinii var. japonica $\times$ L. kaempferi) F . Journal of Forest Research, 11 (3): 157-163. http://dx.'doi.org/10.1007/s10310-005-0200-9.

12. Fujisaki, K., 1985: On the relationship between the anatomical features and the wood quality in the sugi cultivars (1) on CV. Kumotoshi, CV. Yaichi, CV. Yabukuguri and CV. Measa (in Japanese). Bulletin of the Ehime University Forest, 23: 47-58.

13. Fukazawa, K., 1967: The variability of wood quality within a tree of Cryptomeria japonica - characteristics of juvenile and adult wood resulting from various growth conditions and genetic factors. Research Bulletin, Faculty of Agriculture, Gifu University 25:47-127.

14. Gartner, B. L., 1996: Does photosynthetic bark have a role in the production of core vs. outer wood? Wood and Fiber Science, 28 (1): 51-61.

15. Hurst, H. E., 1951: Long-term storage capacity of reservoirs. T. Am. Soc. Civ. Eng., 116: 770-808.

16. Koubaa, A.; Zhang, S. Y. T.; Makni, S., 2002: Defining the transition from earlywood to latewood in black spruce based on intra-ring wood density profiles from Xray densitometry. Annals of Forest Science, 59 (5-6): 511-518. http://dx.doi.org/10.1051/forest:2002035.

17. Larson, P. R., 1968: Silvicultural control of the characteristics of wood used for furnish. In: Tappi Forest Biology Conference 4 New York, Proceedings. Atlanta, 143-150.

18. Maeglin, R., 1987: Juvenile wood, tension wood, and growth stress effects on processing hardwoods. In: Applying the latest research to hardwood problems: Pro- ceedings of the $15^{\text {th }}$ annual hardwood symposium of the Hardwood Research Council. Memphis, TN, 100-108.

19. Matyas, C.; Peszlen, I., 1997: Effect of age on selected wood quality traits of poplar clones. Silvae Genetica, 46 (2-3): 64-72.

20. Mutz, R.; Guilley, E.; Sauter, U. H.; Nepveu, G., 2004: Modelling juvenile-mature wood transition in Scots pine (Pynus sylvestris L.) using non-linear mixed-effects models. Annals of Forest Science, 61 (8): 831-841. http://dx.doi.org/10.1051/forest:2004084.

21. Nowacki, G. J.; Abrams, M. D., 1997. Radial-growth averaging criteria for reconstructing disturbance histories from presenttlement-origin oaks. Ecological Monographs 67 (2): 225-249. http://dx.doi.org/10.1890/00129615(1997)067[0225:RGACFR]2.0.CO;2

22. Ota, S., 1971: Studies on mechanical properties of juvenile wood, especially of sugi-wood and hinoki-wood (in Japanese). Bulletin of Kyushu University of Forestry, 45: 1-80.

23. Peters, E. E., 1994: Fractal Market Analysis: Applying Chaos Theory to Investment and Economics. John Wiley and Sons, Brisbane.

24. Rozenberg, Ph.; Franc, A.; Cahalan, C., 2001: Incorporating wood density in breeding programs for softwoods in Europe: a strategy and associated methods. Silvae Genetica, 50 (1): 1-7.

25. Shiokura, T., 1982: Extent and differentiation of the juvenile wood zone in coniferous tree trunks (in Japanese). Mokuzai Gakkaishi, 28: 85-90.

26. Solomina, O. N.; Aptikaeva, O. I.; Shatalin, A. Y., 2010: Cyclicity of natural processes in the last 300 years imprinted in the tree-ring proxies in subarctic European Russia revealed by wavelet analysis. Izvestiya, Atmospheric and Oceanic Physics, 46 (7): 830-837. http://dx.doi.org/10.1134/S0001433810070030.

27. Torrence, C.; Compo, G., 1998: A practical guide to wavelet analysis. Bulletin of American Meteorological Society, 79 (1): 61-78. http://dx.doi.org/10.1175/15200477(1998)079<0061:APGTWA>2.0.CO;2.

28. Wang, M.; Stewart, J. D., 2013: Modeling the transition from juvenile to mature wood using modulus of elasticity in lodgepole pine. Western Journal of Applied Forestry, 28 (4): 135-142. http://dx.doi.org/10.5849/wjaf.12-026.

29. Yang, K. C.; Benson, C.; Wong, J. K., 1986: Distribution of juvenile wood in two stems of Larix laricina. Canadian Journal of Forest Research, 16 (5): 1041-1049. http://dx.doi.org/10.1139/x86-181.

30. Yang, K. C.; Chen, Y. S.; Chiu, C., 1994: Formation and vertical distribution of juvenile and mature wood in a single stem of Cryptomeria japonica. Canadian Journal of Forest Research, 24 (5): 969-975. http://dx.doi.org/10.1139/x94-127.

31. Zhu, J.; Nakano, T.; Hirakawa, Y.; Zhu, J. J., 2000: Effect of radial growth rate on selected indices of juvenile and mature wood of the Japanese larch. Journal of Wood Science, 46 (6): 417-422. http://dx.doi.org/10.1007/BF00765798.

32. Zhu, J.; Tadooka, N.; Takata, K.; Koizumi, A., 2005: Growth and wood quality of sugi (Cryptomeria japonica) planted in Akita prefecture (II). Juvenile/mature wood determination of aged trees. Journal of Wood Science, 51 (2): 95-101. http://dx.doi.org/10.1007/s10086-004-0623-5

\section{Corresponding address:}

Assoc. Prof. LEVENTE CSOKA, Ph.D.

University of West Hungary

Bajesy Zs. E. u. 4.

9400 Sopron, HUNGARY

e-mail: levente.csoka@skk.nyme.hu 